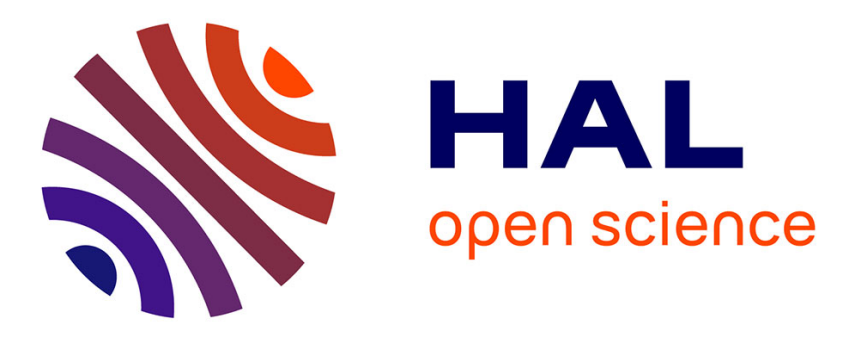

\title{
Eplerenone treatment alleviates the development of joint lesions in a new rat model of spontaneous metabolic-associated osteoarthritis
}

\author{
Chaohua Deng, Arnaud Bianchi, Nathalie Presle, David Moulin, Meriem \\ Koufany, Cécile Guillaume, Hervé Kempf, Anne Pizard
}

\section{To cite this version:}

Chaohua Deng, Arnaud Bianchi, Nathalie Presle, David Moulin, Meriem Koufany, et al.. Eplerenone treatment alleviates the development of joint lesions in a new rat model of spontaneous metabolicassociated osteoarthritis. Annals of the Rheumatic Diseases, 2018, 77 (2), pp.315 - 316. 10.1136/annrheumdis-2016-210700 . hal-01702028

\section{HAL Id: hal-01702028 \\ https://hal.univ-lorraine.fr/hal-01702028}

Submitted on 18 Feb 2022

HAL is a multi-disciplinary open access archive for the deposit and dissemination of scientific research documents, whether they are published or not. The documents may come from teaching and research institutions in France or abroad, or from public or private research centers.
L'archive ouverte pluridisciplinaire HAL, est destinée au dépôt et à la diffusion de documents scientifiques de niveau recherche, publiés ou non, émanant des établissements d'enseignement et de recherche français ou étrangers, des laboratoires publics ou privés. 


\section{EPLERENONE TREATMENT ALLEVIATES THE DEVELOPMENT OF JOINT LESIONS IN A NEW RAT MODEL OF SPONTANEOUS METABOLIC-ASSOCIATED OSTEOARTHRITIS}

\section{Chaohua Deng ${ }^{1,5}$, Arnaud Bianchi ${ }^{1,5}$, Nathalie Presle ${ }^{1,5}$, David Moulin ${ }^{1,4,5}$, Meriem Koufany ${ }^{1,5}$, Cécile Guillaume ${ }^{1,5}$, Hervé Kempf ${ }^{1,5, *,}$ and Anne Pizard $^{2,3,4,5, *, \$}$}

1 UMR 7365 CNRS-Université de Lorraine, IMoPA, Vandoeuvre-lès-Nancy, France.

2 CIC 1433 Inserm, Pierre Drouin, Vandoeuvre-lès-Nancy, France.

3 UMRS U1116 Inserm- Université de Lorraine, DCAC, Vandoeuvre-lès-Nancy, France.

4 CHU Nancy, Contrat d'interface, Vandoeuvre-lès-Nancy, France.

5 Fédération de Recherche 3209, Vandoeuvre-lès-Nancy, France.

\$ equal contribution

* Correspondence to:

Anne Pizard, Inserm U1116, CHRU Nancy, 4 rue du Morvan, Vandoeuvre-lès-Nancy 54500 France.

E-mail: anne.pizard@inserm.fr

Hervé Kempf, UMR 7365 CNRS, IMoPA, 9 avenue de la Forêt de Haye, Vandoeuvre-lès-Nancy 54500 France.

E-mail: herve.kempf@inserm.fr 
Increasing epidemiological and clinical studies suggest that metabolic syndrome (MetS) plays a role in the incidence and progression of osteoarthritis (OA).[1,2] However, in absence of appropriate MetS-associated OA experimental model,[3] the MetS contribution to the joint phenotype in OA remains difficult to investigate and the evaluation of potential disease-modifying OA drugs (DMOADs) is complicated. Noteworthy, in contrast to their lean $\mathrm{SHHF}^{+++}$(spontaneously hypertensive heart failure) controls, obese SHHF ${ }^{\mathrm{cp} / \mathrm{cp}}$ rats, a well-characterized model of MetS,[4] develop drastic metabolic, cardiovascular and renal alterations that are substantially improved through an early chronic mineralocorticoid receptor antagonism (MRA) treatment.[5] Thus, by comparing young (1.5 months) and aged (12.5 months) lean $\mathrm{SHHF}^{+/+}$and obese $\mathrm{SHHF}^{\mathrm{cp} / \mathrm{cp}}$ rats, we sought to evaluate for the first time the potential i) contribution of MetS to joint alterations and ii) therapeutic benefits derived from chronic MRA treatment by eplerenone (Fig1A).

Rats with no MetS $\left({ }^{1.5} \mathrm{SHHF}^{+/+}\right.$and $\left.{ }^{12.5} \mathrm{SHHF}^{+/+}\right)$or with barely developed MetS $\left({ }^{1.5} \mathrm{SHHF}^{\mathrm{cp} / \mathrm{cp}}\right)$ [4] displayed normal knee articular phenotype (Fig1Ba,e,i,m and data not shown for young rats). In striking contrast, ${ }^{12.5} \mathrm{SHHF}^{\mathrm{cp} / \mathrm{cp}}$ rats, affected by culminating MetS conditions,[4] exhibited knee joints with marked fibrillations from the surface to the middle layer of the cartilage (Fig1Bc,g,k) and moderate to severe loss of proteoglycans (Fig1Bg) and collagen II (Fig1Bk) through the entire thickness of the cartilage. These alterations of the ${ }^{12.5} \mathrm{SHHF}^{\mathrm{cp} / \mathrm{cp}}$ knees were associated with pronounced osteophyte formation $(\mathrm{Fig} 1 \mathrm{Bc}, \mathrm{k})$ and with fibrosis, inflammation and cellular infiltration of the synovial tissue $(\mathrm{Fig} 1 \mathrm{Bc}, \mathrm{o})$. Very interestingly, we could demonstrate that a preventive 11-month eplerenone treatment did not alter the normal knee phenotype of ${ }^{12.5} \mathrm{SHHF}^{+/+}$rats (Fig1Bb,f,j,n) but substantially reduced the cartilage damages, osteophyte formation and synovial inflammation observed in placebo ${ }^{12.5} \mathrm{SHHF}^{\mathrm{cp} / \mathrm{cp}}$ rats (compare Fig1Bd,h,l,p with Fig1Bc,g,k,o respectively). Those striking findings were further substantiated by cartilage degeneration, osteophyte formation and synovial membrane inflammation scores, measured according to the last OARSI recommendations for histological assessments in rats[6] (Fig1C). Altogether, this establishes that metabolic disorders in obese $\mathrm{SHHF}^{\mathrm{cp} / \mathrm{cp}}$ rats induce changes in the knee joint that are significantly prevented upon chronic treatment with MRA eplerenone. 
Stratifying OA of various etiologies to attain precision medicine[7] is yet of limited interest as no efficient and specific DMOAD is available for clinical use.[3,7] In this regard, the present pilot study sustains the proof-of-concept that preventive and chronic MRA treatment with the well-known safety profile drug eplerenone may constitute a promising therapeutic strategy effective for MetS patients at increased risk of developing knee OA, especially those with abdominal obesity we very recently reported to be better responder to eplerenone.[8] Interestingly, through the known beneficial impact of eplerenone on cardiac[5] and renal (unpublished data) conditions, plus the hereby supported positive effect on the development of MetS-associated cartilage and synovial lesions, MRA could ease mobility of this subfamily of OA patients. If validated in clinic, such improvement of their life quality might further participate to the decrease of cardiovascular risks in MetS patients by maintaining physical activity.

In conclusion, we uncovered the $\mathrm{SHHF}^{\mathrm{cp} / \mathrm{cp}}$ strain as a unique spontaneous MetS-associated OA model in rat. Although the bone phenotype remains to be characterized, our work highlights the SHHF model as a novel and attractive instrumental tool to evaluate new preventive and curative therapeutics. Actually, using this model, we evidenced that preventive chronic MRA could positively impede the development of OA-like lesions in the articular and synovial tissues of individuals with MetS. Current and future investigations in vitro, in SHHF model and in patients cohorts will help decipher which and how systemic and/or local modulations of MR-downstream pathways[9] are involved in this uncovered beneficial effect of eplerenone in MetS-induced OA lesions. 


\section{Acknowledgments}

This work was supported by Inserm and Région Lorraine.

The sponsors had no role in any experimental part of the study or the writing of the manuscript.

\section{Contributions}

HK and AP conceived the study; $\mathrm{CD}, \mathrm{AB}, \mathrm{NP}, \mathrm{DM}, \mathrm{MK}, \mathrm{CG}$ and $\mathrm{AP}$ performed the experiments; $\mathrm{CD}, \mathrm{AB}, \mathrm{NP}, \mathrm{DM}, \mathrm{MK}, \mathrm{HK}$ and $\mathrm{AP}$ interpreted the data; $\mathrm{CD}, \mathrm{HK}$ and $\mathrm{AP}$ wrote the manuscript.

\section{Competing interests}

None 


\section{References}

1 Zhuo Q, Yang W, Chen J, et al. Metabolic syndrome meets osteoarthritis. Nat Rev Rheumatol 2012;8:729-37. doi:10.1038/nrrheum.2012.135

2 Berenbaum F, Griffin TM, Liu-Bryan R. Review: Metabolic Regulation of Inflammation in Osteoarthritis. Arthritis \& Rheumatology 2016;69:9-21. doi:10.1002/art.39842

3 Courties A, Gualillo O, Berenbaum F, et al. Metabolic stress-induced joint inflammation and osteoarthritis. Osteoarthr Cartil 2015;23:1955-65. doi:10.1016/j.joca.2015.05.016

4 Youcef G, Olivier A, L'Huillier CPJ, et al. Simultaneous characterization of metabolic, cardiac, vascular and renal phenotypes of lean and obese SHHF rats. PLoS ONE 2014;9:e96452. doi:10.1371/journal.pone.0096452

5 Youcef G, Olivier A, Nicot N, et al. Preventive and chronic mineralocorticoid receptor antagonism is highly beneficial in obese SHHF rats. Br J Pharmacol 2016;173:1805-19. doi:10.1111/bph.13479

6 Gerwin N, Bendele AM, Glasson S, et al. The OARSI histopathology initiative recommendations for histological assessments of osteoarthritis in the rat. Osteoarthritis and Cartilage 2010;18:S24-S34. doi:10.1016/j.joca.2010.05.030

7 Bijlsma JWJ, Berenbaum F, Lafeber FPJG. Osteoarthritis: an update with relevance for clinical practice. Lancet 2011;377:2115-26. doi:10.1016/S0140-6736(11)60243-2

8 Olivier A, Pitt B, Girerd N, et al. Effect of eplerenone in patients with heart failure and reduced ejection fraction: potential effect modification by abdominal obesity Insight from EMPHASIS-HF trial. European Journal of Heart Failure doi:10.1002/ejhf.792

9 Jaisser F, Farman N. Emerging Roles of the Mineralocorticoid Receptor in Pathology: Toward New Paradigms in Clinical Pharmacology. Pharmacol Rev 2016;68:49-75. doi:10.1124/pr.115.011106 
A

(Lean)

(Obese)

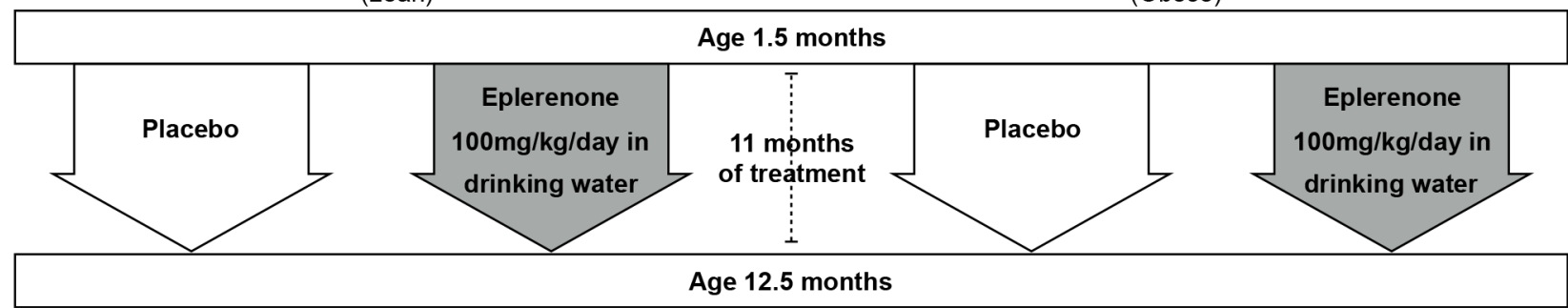

B

12.5SHHF+/+Eple

12.5SHHFcp/cp

12.5SHHFcp/cpEple
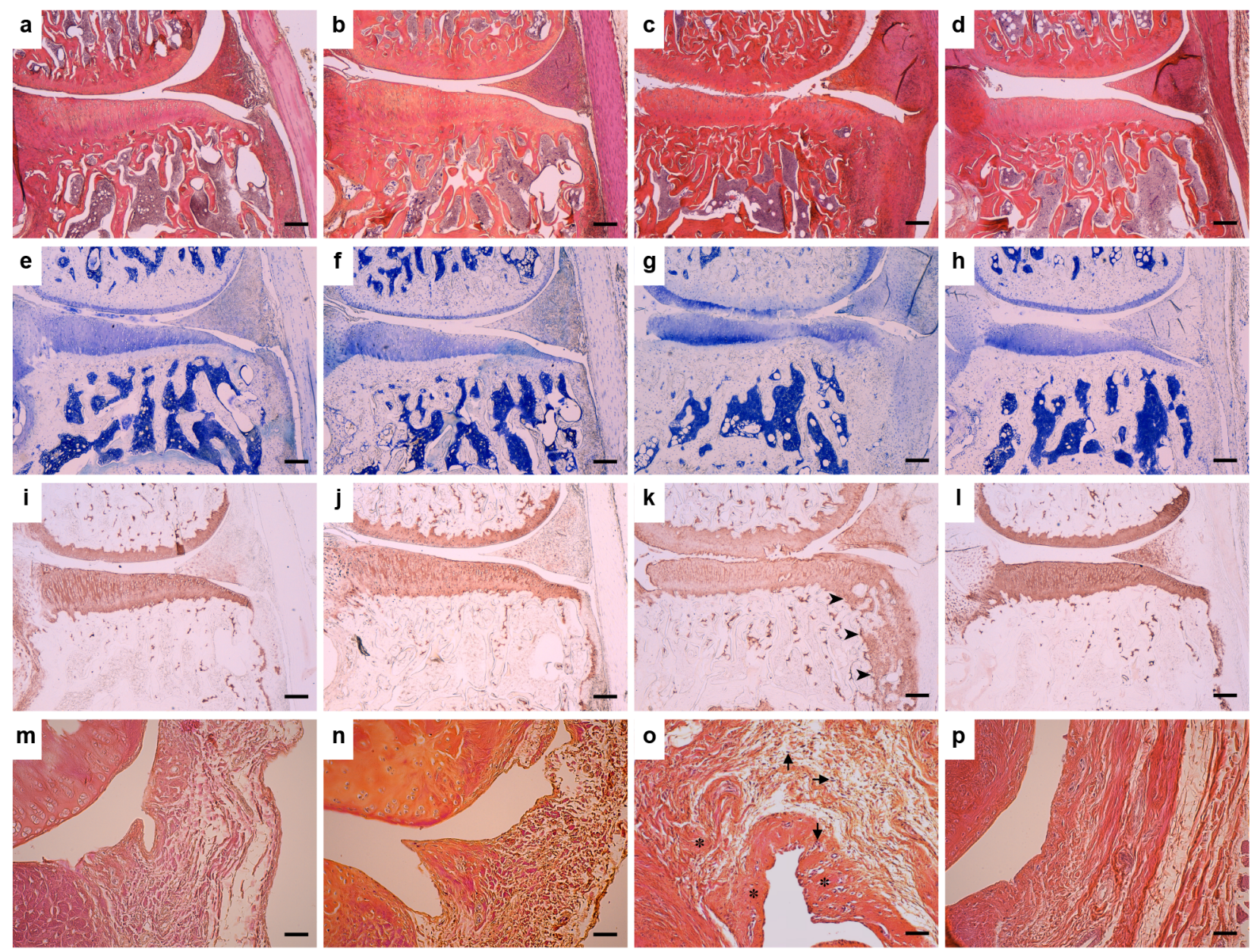

C

Cartilage degeneration score
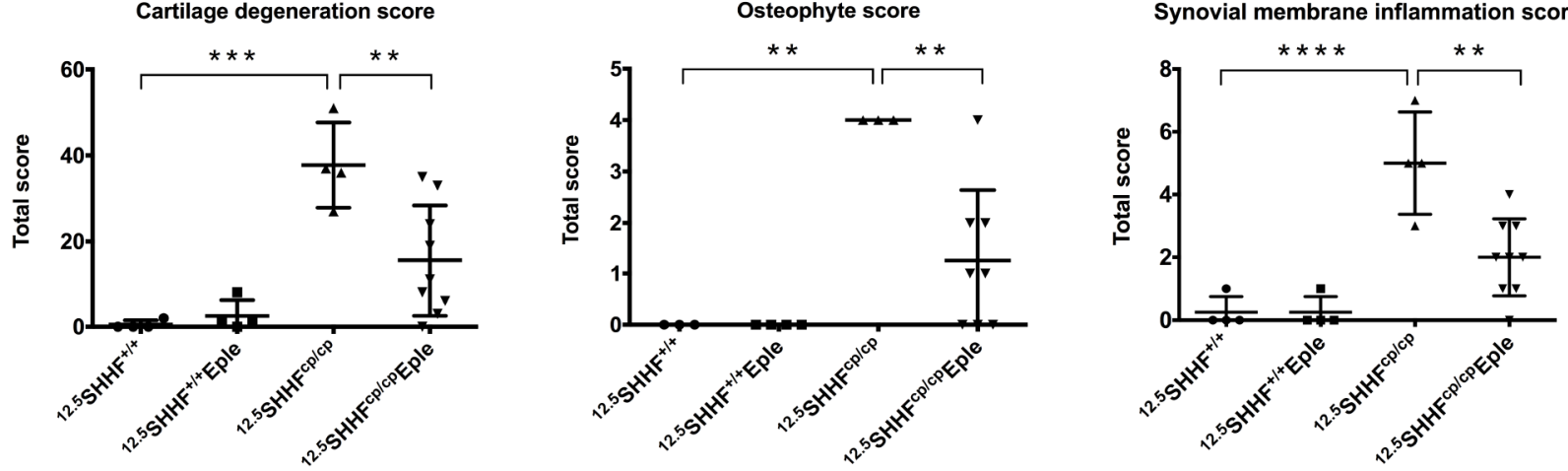